\title{
Severe acute pyelonephritis: a review of clinical outcome and risk factors for mortality
}

\author{
Vera Y Chung *, CK Tai, CW Fan, CN Tang
}

\section{A B S T R A C T}

Objective: To review demographics of patients with acute pyelonephritis, their outcomes of severe upper urinary tract infection, and to identify risk factors for long hospital stay and mortality.

Design: Case series.

Setting: A regional hospital in Hong Kong.

Patients: Patients admitted between June 2007 and June 2012 for acute pyelonephritis were identified. Those with the most severe outcomes were analysed of their mortality, need for care in the intensive care unit, or necessitation of urological intervention.

Results: Overall, 68 patients fulfilled our criteria for severe acute pyelonephritis. The female-to-male ratio was $7: 3$. Their mean age was 58 years. Overall, $57 \%$ of the patients had impaired renal function and $37 \%$ were diabetic; $47 \%$ developed shock after admission and $56 \%$ required further intensive care unit care; $75 \%$ of the patients demonstrated radiological evidence of urinary tract obstruction and required subsequent drainage procedures. Five patients died due to severe acute pyelonephritis. The prevalence of bacteraemia and bacteriuria was $57 \%$ and $74 \%$, respectively. Escherichia coli accounted for the majority of causative organisms. Four risk
This article was published on 14 Mar 2014 at www.hkmj.org. with hospital stay of longer than 14 days. Old age ( $\geq 65$ years), male sex, deranged renal function, and presence of disseminated intravascular coagulation were associated with mortality.

Conclusion: There was high prevalence of bacteraemia and septic shock in patients with severe acute pyelonephritis. The factors of old age ( $\geq 65$ years), male sex, deranged renal function, and presence of disseminated intravascular coagulation were associated with mortality. With the support of intensive care, early recognition of urinary tract obstruction and timely drainage, patients with severe acute pyelonephritis generally carry a good prognosis.

\section{Hong Kong Med J 2014;20:285-9}

\section{DOI: 10.12809/hkmj134061}

VY Chung *, FHKAM (Surgery), FRCS (Edin)

CK Tai, FHKAM (Surgery), FRCS (Edin)

CW Fan, FHKAM (Surgery), FRCS (Edin)

CN Tang, FHKAM (Surgery), FRCS (Edin)

Division of Urology, Department of Surgery, Pamela Youde Nethersole Eastern Hospital, Chai Wan, Hong Kong

* Corresponding author: chungyeungvera@gmail.com

New knowledge added by this study

- Contrary to the usual belief, the complexity of renal infections and septic shock were predictors for long hospital stay but not mortality.

- Escherichia coli still accounts for the majority of causative organisms in hospitalised patients with severe acute pyelonephritis.

Implications for clinical practice or policy

- Early recognition of urinary tract obstruction and timely drainage are important in the treatment of severe acute pyelonephritis.

- Physicians could prevent potential mortalities by identifying those with risk factors and providing early intervention and intensive care.

\section{Introduction}

Acute pyelonephritis (AP) represents the most severe form of urinary tract infection (UTI) and is associated with significant morbidity and even mortality. Approximately 250000 cases of AP occur each year in the US, with the incidence being higher in women than men. ${ }^{1}$ The aetiological agent is Escherichia coli in around $80 \%$ of the cases. ${ }^{2}$ Acute pyelonephritis has a quoted mortality of $10 \%$ to $20 \%{ }^{3}$ Several studies have identified a number of risk factors for prediction of poor outcome, including urinary tract abnormality, general debility, and properties (ie virulence and resistance profile) of microorganisms. ${ }^{4,5}$

The aim of this study was to review patient demographics and outcomes of severe AP in a 


\section{嚴重急性腎炎的臨床治療結果及導致死亡的 風險因素}

\author{
鍾楊、戴志健、樊志偉、鄧宗毅
}

目的：分析嚴重急性腎炎病人的人口學數據和治療結果, 並評估導致 住院時間延長及死亡的風險因素。

設計：病例系列。

安排：香港一所分區醫院。

患者：2007年6月至2012年6月期間因急性腎炎入院的病人, 如果符 合嚴重腎炎的臨床標準便會被納入研究範圍, 並分析其死亡率、在深 切治療病房所需的照顧和是否曾接受緊急泌尿科介入手術。

結果：共分析 68 位患者的情況。男女比例為 $3: 7$; 平均年齡 58 歲。5 7 \% 病人入院時腎功能受損, $37 \%$ 為糖尿病患者。 $47 \%$ 病人入院 後出現感染性休克, $56 \%$ 病情惡化需要ICU監護。75\%患者的超聲或 $\mathrm{CT}$ 掃描顯示腎積水, 並接受引流。共5位病人因腎炎死亡。菌血率及 菌尿率分別為 $57 \%$ 及 $74 \%$ 。大腸桿菌仍然為最常見的致病菌。本研究 發現以下四項因素與住院時間延長（多於14日）有直接關聯：菌血 㿈、感染性休克、危重病情而需要在深切治療病房接受監護, 以及化 膿性腎炎。患者年齡在65歲或以上、男性、腎功能受損及彌散性血管 內凝血則會增加病人死亡的風險。

結論：在嚴重急性腎炎的住院病人中, 菌血率及感染性休克率相對較 高。年長患者（65歲或以上）、男性、腎功能受損及彌散性血管內凝 血可能增加死亡機會。如果能接受深切治療、及早發現尿道阻塞和及 時進行引流, 腎炎患者的預後普遍比較理想。

TABLE I. Patient demographics and clinical data

\begin{tabular}{lc}
\hline Variable & No. (\%) of patients* \\
\hline Mean (range) age (years) & $58(12-88)$ \\
\hline Age $\geq 65$ years & $26(38.2)$ \\
\hline Gender (female/male) & $48(70.6) / 20(29.4)$ \\
\hline Diabetes mellitus & $25(36.8)$ \\
\hline Deranged renal function (creatinine $>160 \mathrm{mmol} / \mathrm{L}) \dagger$ & $39(57.4)$ \\
\hline Bacteriuria & $50(73.5)$ \\
Bacteraemia & $39(57.4)$ \\
Urinary tract obstruction (presence of hydronephrosis in & $51(75.0)$ \\
imaging) & $6(8.8)$ \\
\hline Suppurative renal infections $\ddagger$ & $51(75.0)$ \\
Urological interventions & $38(55.9)$ \\
Need for intensive care & $32(47.1)$ \\
\hline Septic shock & $12(3-46)$ \\
\hline Mean (range) length of stay (days) &
\end{tabular}

* Except otherwise indicated

$\dagger$ Renal function test upon admission

‡ Diagnosis by computed tomography as one of the following: suppurative collections confined to renal parenchyma, extended infection into adjacent tissue, gas-forming infections, bilateral or multiple collections ${ }^{6}$ regional hospital, and to identify possible prognostic factors for long hospital stay and fatal events.

\section{Methods}

\section{Study design and data collection}

We conducted a retrospective medical record review. All patients admitted for AP between June 2007 and June 2012 to Pamela Youde Nethersole Eastern Hospital, Hong Kong were identified. Only patients with the most severe outcomes were analysed consecutively: (1) mortality, (2) need for care in the intensive care unit (ICU), or (3) necessitation of urological intervention. Patients suffering from postoperative pyelonephritis were excluded.

The following data were collected: patient demographics, presence of urinary tract obstruction, presence of septic shock, need for intensive care, modalities of urological intervention, bacteriologies, length of stay, and mortality.

\section{Statistical analysis}

Data analysis was performed by the Statistical Package for the Social Sciences (Windows version 20; SPSS Inc, Chicago [IL], US). A P value of less than 0.05 was regarded as statistically significant. Chi squared test and logistic regression analysis were performed. The independent variables were patients' demographic and clinical data; the dependent variables were mortality and long hospital stay ( $>14$ days).

\section{Results}

\section{Patient characteristics}

A total of 432 patients were admitted for AP from June 2007 to June 2012. Of these, 68 patients fulfilled our inclusion criteria for severe AP. Baseline patient demographics, clinical characteristics, and imaging findings are illustrated in Table $1 .^{6}$ Overall, $75.0 \%$ of the patients $(n=51)$ demonstrated radiological evidence of urinary tract obstruction, secondary to stone $(51.0 \%)$, ureteral stricture $(5.8 \%)$, or extrinsic compression (7.2\%). Six patients had suppurative renal infections, namely, renal abscess and emphysematous pyelonephritis.

\section{Microbiology}

The yields of blood culture were positive in $57.4 \%$ of the patients, with $E$ coli being the commonest causative organism (38.2\%) followed by Klebsiella pneumoniae, Proteus mirabilis, and Acinetobacter species. Only three patients had bacteraemia caused by extended-spectrum $\beta$-lactamase-producing $E$ coli (Table 2).

The prevalence of bacteriuria was $73.5 \%$, and $E$ coli accounted for the majority of cases with bacteriuria, followed by $K$ pneumoniae and Pseudomonas aeruginosa (Table 2). 


\section{Urological procedure}

In addition to antibiotic administration, $75 \%(n=51)$ of the patients required urological interventions, including percutaneous nephrostomy $(n=41)$, insertion of ureteric stent $(n=5)$, percutaneous drainage $(n=1)$, and nephrectomy $(n=5)$.

\section{Mortality due to pyelonephritis}

The overall mortality was $7.4 \%(n=5)$. Table 3 summarises the characteristics of patients who died due to pyelonephritis within the same admission.

\section{Prognostic factors for long hospital stay and mortality}

Risk factors for long hospital stay ( $>14$ days; $32.4 \%$ ) and mortality (7.4\%) were analysed (Tables 4 and 5 ).

Presence of bacteraemia $(\mathrm{P}=0.022)$, suppurative pyelonephritis $(\mathrm{P}=0.005)$, shock $(\mathrm{P}=0.016)$, and need for ICU care $(\mathrm{P}=0.003)$ were significant risk factors for long hospital stay on univariate analysis. On multivariate analysis, the odds ratios (ORs) were 3.71 for bacteraemia $(\mathrm{P}=0.026), 13.23$ for suppurative

TABLE 2. Results of blood and urine culture

\begin{tabular}{lcc}
\hline Microorganism & \multicolumn{2}{c}{ No. (\%) of patients } \\
\cline { 2 - 3 } & Bacteraemia & Bacteriuria \\
\hline Escherichia coli & $26(38.2)$ & $31(45.6)$ \\
ESBL +ve Escherichia coli & $3(4.4)$ & $4(5.9)$ \\
Klebsiella pneumoniae & $4(5.9)$ & $4(5.9)$ \\
Proteus mirabilis & $3(4.4)$ & $2(2.9)$ \\
Acinetobacter species & $2(2.9)$ & $2(2.9)$ \\
Pseudomonas aeruginosa & 0 & $4(5.9)$ \\
Other & $1(1.5)^{\star}$ & $3(4.4) \dagger$ \\
Total & $\mathbf{3 9 ( 5 7 . 4 )}$ & $\mathbf{5 0}(\mathbf{7 3 . 5 )}$ \\
\hline
\end{tabular}

Abbreviation: $\mathrm{ESBL}=$ extended-spectrum $\beta$-lactamase

* Citrobacter koseri

† Citrobacter koseri, Salmonella, and methicillin-resistant Staphylococcus aureus pyelonephritis $(\mathrm{P}=0.022), 3.65$ for shock $(\mathrm{P}=0.018)$, and 5.85 for ICU care $(\mathrm{P}=0.005)$.

On univariate analysis, age of $\geq 65$ years, male sex, deranged renal function, and disseminated intravascular coagulation (DIC) were predictors for death. However, only male sex $(\mathrm{OR}=11.75 ; \mathrm{P}=0.033)$ and DIC (OR=10.31; $\mathrm{P}=0.018)$ were shown to be independent risk factors in multivariate regression analysis.

\section{Discussion}

Severe AP is an important disease entity that frequently requires hospitalisation. Early recognition of patients who are at risk of prolonged hospital stay or even fatal events is important to improve treatment results. Previous studies ${ }^{4,5}$ have shown a number of risk factors including immunosuppression, old age, and diabetes as risk factors for treatment failure. We were interested in finding whether these risk factors also applied to the local Hong Kong population.

An epidemiological study in the US found that women are approximately 5 times more likely than men to be hospitalised for AP; however, women have a lower mortality rate than men. ${ }^{7}$ In our study of hospitalised patients, females accounted for the majority (70.6\%) of AP cases. However, all but one mortality from pyelonephritis occurred in the male patients.

In one study on AP in adults, $E$ coli was the aetiological agent in $80 \%$ of the cases, but $E$ coli infections were less common in elderly patients (60\%). Furthermore, infections due to $P$ mirabilis, $K$ pneumoniae, Serratia marcescens, and $P$ aeruginosa were very common due to the increased use of catheters. ${ }^{2}$ Our study showed a similar microbial spectrum. However, in AP, it is not always possible to routinely document clinical UTI. This could be attributed to previous antibiotic treatment, low bacterial growth, or presence of atypical pathogens. ${ }^{8}$ In the present analysis, it was possible that a certain proportion of patients had received antibiotic treatment before admission to the hospital. Despite this, the prevalence of bacteraemia and bacteriuria

TABLE 3. Details of patients who died due to acute pyelonephritis

\begin{tabular}{lcccccccccccc}
\hline $\begin{array}{l}\text { Patient } \\
\text { No. }\end{array}$ & $\begin{array}{c}\text { Age } \\
\text { (years) }\end{array}$ & Gender & DM & $\begin{array}{c}\text { Deranged } \\
\text { renal } \\
\text { function }\end{array}$ & $\begin{array}{c}\text { Urinary } \\
\text { tract } \\
\text { obstruction }\end{array}$ & $\begin{array}{c}\text { Ureteral } \\
\text { stone }\end{array}$ & Bacteraemia & Shock & DIC & $\begin{array}{c}\text { Intensive } \\
\text { care }\end{array}$ & $\begin{array}{c}\text { Urological } \\
\text { interventions }\end{array}$ & $\begin{array}{c}\text { Hospital } \\
\text { stay } \\
\text { (days) }\end{array}$ \\
\hline 1 & 77 & M & No & Yes & Yes & Yes & - & Yes & Yes & Yes & PCN & 5 \\
2 & 75 & M & Yes & Yes & Yes & Yes & $E$ coli & Yes & Yes & Yes & PCN & 36 \\
3 & 88 & M & Yes & Yes & Yes & Yes & ESBL E coli & Yes & Yes & - & PCN & 4 \\
4 & 84 & F & No & Yes & Yes & - & ESBL E coli & - & - & - & - & 12 \\
5 & 52 & M & Yes & Yes & Yes & Yes & Gram-positive bacilli & Yes & Yes & Yes & PCN & 16 \\
\hline
\end{tabular}

Abbreviations: $\mathrm{DIC}=$ disseminated intravascular coagulation; $\mathrm{DM}=$ diabetes mellitus; $\mathrm{E}$ coli $=$ Escherichia coli; $\mathrm{ESBL}=$ extended-spectrum $\beta$-lactamase; $\mathrm{PCN}=$ percutaneous nephrostomy 
TABLE 4. Prognostic factors for long hospital stay (>14 days)

\begin{tabular}{lcccc}
\hline Variable & $\begin{array}{c}\text { P value (univariate } \\
\text { analysis) }\end{array}$ & $\begin{array}{c}\text { P value (multivariate } \\
\text { analysis) }\end{array}$ & OR & 95\% CI \\
\hline Age $\geq 65$ years & 0.404 & - & - & - \\
Male sex & 0.403 & - & - & - \\
\hline Diabetes mellitus & 0.121 & - & - & - \\
Deranged renal function & 0.078 & - & - & - \\
\hline Urinary tract obstruction & 0.769 & - & - & - \\
\hline Bacteraemia & 0.022 & 0.026 & 3.71 & $1.17-11.75$ \\
Bacteriuria & 0.497 & - & - & - \\
Suppurative pyelonephritis & 0.005 & 0.022 & 13.23 & $1.44-121.66$ \\
\hline Shock & 0.016 & 0.018 & 3.65 & $1.24-10.75$ \\
\hline Disseminated intravascular coagulation & 0.318 & - & - & - \\
ICU care & 0.003 & 0.005 & 5.85 & $1.71-20.02$ \\
Urological intervention & 0.769 & - & - & - \\
\hline
\end{tabular}

Abbreviations: $\mathrm{Cl}=$ confidence interval; $\mathrm{ICU}=$ intensive care $\mathrm{unit}$; $\mathrm{OR}=$ odds ratio

TABLE 5. Prognostic factors for mortality

\begin{tabular}{lcccc}
\hline Variable & $\begin{array}{c}\text { P value (univariate } \\
\text { analysis) }\end{array}$ & $\begin{array}{c}\text { P value (multivariate } \\
\text { analysis) }\end{array}$ & OR & 95\% Cl \\
\hline Age $\geq 65$ years & 0.046 & 0.080 & - & - \\
Male sex & 0.010 & 0.033 & 11.75 & $1.22-113.0$ \\
\hline Diabetes mellitus & 0.270 & - & - & - \\
\hline Deranged renal function & 0.045 & 0.098 & - & - \\
\hline Urinary tract obstruction & 0.185 & - & - & - \\
\hline Bacteraemia & 0.294 & - & - & - \\
Bacteriuria & 0.738 & - & - & - \\
\hline Suppurative pyelonephritis & 0.447 & - & - & - \\
\hline Shock & 0.129 & - & 10.31 & $1.487-71.534$ \\
Disseminated intravascular coagulation & 0.006 & 0.018 & - & - \\
ICU care & 0.850 & - & - & - \\
\hline Urological intervention & 0.792 & - & - \\
\hline
\end{tabular}

Abbreviations: $\mathrm{Cl}=$ confidence interval; $I C U=$ intensive care unit; $\mathrm{OR}=$ odds ratio

was relatively high $(57.4 \%$ and $73.5 \%$, respectively). occur more commonly in subjects with diabetes Escherichia coli accounted for the majority of than in the general population, and the risk of upper causative organisms.

An obstructed and infected kidney is a urological emergency that may progress to septic shock. Since acute obstructive uropathy raises the renal pelvic pressure and, theoretically, decreases the uptake of drugs by the kidney, emergency drainage is warranted. A urological intervention significantly increases the chances of good initial outcome.6,9 In this study, all patients who showed radiological evidence of urinary tract obstruction were treated with emergency drainage.

It has been suggested that bacteriuria and UTI of patients. 
Recent reports ${ }^{4,13}$ have shown other risk factors such as long-term catheterization and age of $>65$ years to be predictive of prolonged hospitalisation. Our study revealed that four risk factors-including bacteraemia, shock, need for intensive care, and suppurative pyelonephritis-were associated with long hospital stay. These four risk factors were closely related with and denoted the most severe degree of pyelonephritis, thus resulting in longer hospitalisation.

The mortality rate for patients with pyelonephritis has been reported to be $1.2 \%$ to $33 \%{ }^{14,15}$ In our study, which included more severe group of AP patients (ie those who required intensive care or urological interventions), the overall mortality rate was $7.4 \%$. According to a previous study, ${ }^{4}$ septic shock, bedridden status, age of $>65$ years, recent use of antibiotics, and immunosuppression were independent predictors of death. Another research found that baseline health status of patients and complexity of suppuration were the most important predictors of clinical outcomes for suppurative renal infections. ${ }^{6}$ In our analysis, patients who died due to AP were predominantly older than 65 years, presented with septic shock, and required drainage for urinary tract obstruction. Among the risk factors studied, age of $\geq 65$ years, male sex, deranged renal function, and DIC were associated with mortality in univariate analysis. Additional multivariate correlates were male sex and presence of DIC.

The limitation of the study was that the study population consisted of a heterogeneous group of patients and might not be representative of the majority of uncomplicated AP cases. Presence of resistant pathogens may contribute to treatment failure, but we did not estimate this factor in our analysis. Nevertheless, the outcomes of severe AP also bear clinical implications for physicians who mainly treat critically ill, hospitalised patients.

\section{Conclusion}

There was high prevalence of bacteraemia and septic shock in patients with severe AP, with $E$ coli being the predominant causative organism. Male sex and presence of DIC were associated with mortality. Early recognition of risk factors can potentially help prevent death from severe AP.

\section{References}

1. Ramakrishanan K, Scheid DC. Diagnosis and management of acute pyelonephritis in adults. Am Fam Physician 2005;71:933-42.

2. Stamm WE, Hooton TM. Management of urinary tract infections in adults. N Engl J Med 1993;329:1328-34.

3. Roberts FJ, Geere IW, Coldman A. A three-year study of positive blood cultures, with emphasis on prognosis. Rev infect Dis 1991;13:34-6.

4. Efstathiou SP, Pefanis AV, Tsioulos DI, et al. Acute pyelonephritis in adults: prediction of mortality and failure of treatment. Arch Int Med 2003;163:1206-12.

5. Pertel PE, Haverstock D. Risk factors for a poor outcome after therapy for acute pyelonephritis. BJU Int 2006;98:1417.

6. Stojadinović MM, Mićić SR, Milovanović DR, Janković SM. Risk factors for treatment failure in renal suppurative infections. Int Urol Nephrol 2009;41:319-25.

7. Foxman B, Klemstine KL, Brown PD. Acute pyelonephritis in US hospitals in 1997: hospitalization and in-hospital mortality. Ann Epidemiol 2003;13:144-50.

8. Rollino C, Beltrame G, Ferro M, Quattrocchio G, Sandrone M, Quarello F. Acute pyelonephritis in adults: a case series of 223 patients. Nephrol Dial Transplant 2012;27:3488-93.

9. Yamamoto Y, Fujita K, Nakazawa S, et al. Clinical characteristics and risk factors for septic shock in patients receiving emergency drainage for acute pyelonephritis with upper urinary tract calculi. BMC Urology 2012;12:4.

10. Stapleton A. Urinary tract infections in patients with diabetes. Am J Med 2008;113:80-4.

11. Patterson JE, Andriole VT. Bacterial urinary tract infections in diabetes. Infect Dis Clin North Am 1995;9:25-51.

12. Lye WC, Chan RK, Lee EJ, Kumarasinghe G. Urinary tract infections in patients with diabetes mellitus. J Infect 1992;24:169-74.

13. Roberts JA. Management of pyelonephritis and upper urinary tract infections. Urol Clin North Am 1999;26:75363.

14. Lee JH, Lee YM, Cho JH. Risk factors of septic shock in bacteremic acute pyelonephritis patients admitted to an ER. J Infect Chemother 2012;18:130-3.

15. Yoshimura K, Utsunomiya N, Ichioka K, Ueda N, Matsui Y, Terai A. Emergency drainage from urosepsis associated with upper urinary tract calculi. J Urol 2005;173:458-62. 